\title{
Conservative Mennonite Storybooks and the Construction of Evangelical Separatism
}

Jennifer Anderson ${ }^{1}$

Special Education

Holmes County Training Center

Millersburg, $\mathrm{OH}$

Cory Anderson

Adjunct Professor

Rural Sociology

Ohio State Agricultural Technical Institute

\begin{abstract}
Group-produced literature is representative of and reinforces group behaviors, norms, and beliefs. This study focuses on the missionary theme in literature from three Conservative Mennonite publishers, identifying two major constructs of what we term evangelical separatism. First, Rod \& Staff depicts evangelism as establishing stable, integrating church communities in places where none exist, making their offering accessible to any who would care to join while also withholding assessment of outsiders. Second, Christian Light Publications and TGS present missions in a more aggressive, individualized mode, whereby the outside is viewed as a land of darkness and the missionary, in embodying Christ's incarnation, bring light to that place. The focus of evangelism is conversion to Christianity, with the church as a social system peripheral to the action. Separatism is maintained by staking claim to authentic Christianity against inferior outside offerings. This latter plotline has birthed the new missionary adventure genre, which both entertains readers through secular adventure techniques while emphasizig a sacred end mission. The classic Anabaptist suffering theme is present in both types of stories, though transformed to include social / personal sacrifices and patience needed to engage in mission work.
\end{abstract}

\section{Keywords}

Conservative Mennonite; Amish-Mennonite; TGS, International; Christian Light Publications; Rod \& Staff Publishers; Adventure stories; Literary analysis 


\section{Introduction}

Conservative Mennonite ${ }^{1}$ literature has transformed from occasional unrefined selfpublications of localized interest to a sprawling capitalist market. With the consolidation of Conservative Mennonite publishing around several major companies and their coordination of demand-driven production, the opportunity now exists to comb a wide literature to understand how Conservative Mennonites construct their world.

In the absence of literary research about Conservative Mennonites, this article relies on theoretical discussions of Old Order Amish literary behaviors. Like Amish books, Conservative Mennonite books are a way to construct and code shared systems of meaning (Enninger 1988; Oyabu, Ido and Sugihara 2001). Their literature is, as one Amish scholar reasoned, like a manifesto, an authoritative, public declaration from which cultural priorities can be discerned (Olshan 1988). The very fact that Mennonite texts (like Amish texts) primarily topicalize religion and the community (Enninger 1988) suggests the existence of defining behaviors, norms, and beliefs that differ from a surrounding world that does not share the same ethnicity, religion, or community (Enninger 1986). By implication, then, books not only teach readers what it takes to identify with the community, but the very act of reading the same internally focused texts creates a body of shared action and knowledge (Fishman 1987). Upon each new publication, texts reaffirm what is important to the group and gives readers a broader sense of Conservative Mennonite identity (Galindo 1994). On the other hand, literature also depicts diverging realizations of universally shared institutions, such as the ways Beachy Amish-Mennonite women understand family (Anderson 2013). This article's goal is to uncover those shared systems of meaning - defining behaviors, norms, and beliefs - that constitute the Conservative Mennonite cosmos, with a particular focus on how they similarly and contrastingly synthesize separatism and evangelism.

A distinguishing landmark of Conservative Mennonite identity is their acceptance of American evangelicalism, in particular evangelicalism's culmination in the 1950s renewals that flamed global missions, tent revival meetings, and tract distribution. Conservative Mennonites believe in mission work and coordinated outreach paralleling broader fundamentalist evangelical efforts. Despite this outward focus, the church continues to be a central, guiding force in members' lives, as with distinctive dress, women's head coverings, and proscriptions on some electronic media, including television, with varying conclusions on internet, radio, and/or films (Scott 1996).

Partly because of media restrictions, reading remains an important source of mediated

\footnotetext{
${ }^{1}$ This study uses “Conservative Mennonite” (adjective / noun), “Conservative” (adjective), and "Mennonite” (noun) interchangeably. See Scott (1996) and Anderson (2013) for a listing of Conservative Mennonite affiliations. The Amish-Mennonites, another Conservative group though within the Amish religious tradition, are included in the treatment of Conservative literature here.
} 
cultural information. As with the Amish (Fishman 1988), reading has a central place in family activities. Storylines often become a conversational topic at gatherings. Family members read to young children. Mennonites, like Amish, read works produced both by their own people and outsiders (Miller and Aguilar 1984; St. Clair 2005), though Mennonite-published books are prioritized. Popular Mennonite authors like Harvey Yoder, Pablo Yoder, and Christmas Carol Kauffman consistently attract an eager readership. Conservative Mennonites also faithfully buy books about people personally known. Advertising and publicity plays on this fact. For example, in 2014, Emma: A Will to Surrender, a biography of a Lancaster County native, was aggressively advertized in Lancaster County Mennonite stores through book displays, posters, road signs, and advertisements.

Conservative Mennonite books come primarily from three publishers: Rod \& Staff (R\&S), Christian Light Publications (CLP), and The Good Samaritan (TGS) International. ${ }^{2}$ These publishers consider their work an internal ministry; much material is circulated and written for Mennonite people and other plain readers. ${ }^{3}$ Thus supported by churches and constituencies, Mennonite publishing houses aim to reinforce religious teachings and affirm their societal location as evangelical separatists. They offer two major genres to achieve this goal: religiously themed lifestyle / self-help books (e.g. John Coblentz's Christian Family Living) and storybooks based on actual events; this study focuses on the latter. As with the Amish, Mennonites uniformly read their publishers' stories as non-fiction and true, or, at the very least, within the range of potential everyday life experiences. The absence of fiction is due to the genre being out of tune with Mennonites’ pragmatic and religious ethos, which stresses the unquestionably real over fantasies out of sync with God's created order (Enninger 1988).

Rod \& Staff serves the most conservative of the Mennonites and Amish-Mennonites (e.g. Nationwide Fellowship, Washington-Franklin Conference, Eastern Pennsylvania Mennonite Church, and Mennonite Christian Fellowship). These books have hand-drawn covers and illustrations, promoting by design non-digital free-hand art. They avoid fantasy elements (no animal animation). Stories are about everyday, real-life situations, especially home life. Characters operate within gender roles. Rather than a continual plotline, stories consist of small vignettes from everyday life. While some stories teach children about other cultures, the settings are usually places where their churches have missions, suggesting life is adequately experienced within Mennonite enclaves.

Rod \& Staff states that they are

...a religious publisher with a strong emphasis on holy living and on accepting the

\footnotetext{
${ }^{2}$ Secondary Conservative Mennonite and Amish-Mennonite publishers include Lamp and Light Publishers (Nationwide Fellowship), Vision Publishing (private), Amish-Mennonite Publications and Abana Books (private), and Eastern Mennonite Publications (Eastern Pennsylvania Mennonite Church).

${ }^{3}$ Many fundamentalist homeschoolers use CLP and R\&S materials, the former intentionally soliciting this market.
} 
Scriptures as the rule and guide of our lives [...], offering storybooks with strong Christian teaching. We provide food for the reading diet, not detracting from the Scriptures or supplanting them, but reinforcing them with application [...] Christians should read literature that obligates the reader to the Lord.

With an emphasis on living out Christianity, R\&S writes less explicitly about missions despite being very active in international church planting and domestic outreach programs. They believe living the Christian example will prompt people to want to become Christian. Thus, R\&S books concentrate on building Christian character to achieve a mission-oriented end goal.

Christian Light Publications (CLP) serves less strict audiences (Mid-Atlantic Fellowship, Midwest Fellowship, Southeast Conference, and Beachy Amish-Mennonite). Their stories are largely based on true accounts and have a flowing plotline, with some suspense and thrill. Thus, these are more entertainment-based than R\&S. CLP focuses on teaching an overarching lesson based on characters yielding to God's will or revealing an act of God in a situation or a person's life. While originally CLP illustrated books with freehand art, in the past decade CLP has adopted graphic art, including Mennonite models and computer stock images / poses reminiscent of secular fiction book covers. ${ }^{4}$

More so than R\&S, CLP uses its literature for explicit outreach efforts. CLP’s mission statement is that they are "to help bring people to Christ though the new birth, and giving them encouragement and guidance in their Christian growth.” CLP books have been shifting away from a largely internal focus to explicit mission awareness through book offerings. They express this through blurring sect-distinctive symbols, as with the clothing models wear (e.g. using generic style women's veils in lieu of affiliation-specific Mennonite caps, or positioning the model to hide the covering altogether), multicultural representation (e.g. multiracial children on vacation Bible school covers), and trendy colloquialisms (e.g. the book title Our God is Awesome).

The Good Samaritan (TGS) International is a subsidiary of Christian Aid Ministries (CAM), a non-profit venue primarily supported by Conservative Mennonites, AmishMennonites, New Conference German Baptists, New Order Amish, and Old Order Mennonites. CAM provides global humanitarian aid. TGS's mission is to "give a glimpse of needs around the world and CAM projects and programs.” Foreign cultures are mediated through TGS books and their Vacation Bible School and Sunday school giving programs. Their books are intended to

not merely entertain, but to inspire to a deeper appreciation of godly values and our rich spiritual heritage [...] We hope they will inspire in you a greater desire to serve God and to enlarge His kingdom at home and abroad.

\footnotetext{
${ }^{4}$ On the cover of Weeping for Abigail, Abigail poses with a longing glance toward, but not at, the reader; Conservative Mennonite models surround her in a tableau.
} 
TGS books depict first hand conditions of global setbacks. Photographs are at times raw, exposing suffering, disease, and poverty, especially of children. TGS informs readers about needs, yet simultaneously reinforces their culture by showing the advantages and wealth North American Mennonites possess.

\section{Method}

The publications of Rod \& Staff, CLP, and TGS were employed as representative of Conservative Mennonite beliefs and orientations for two reasons. First, their sheer size and visibility suggests a large support base. Second, many reviewers and committees comb manuscripts for content potentially objectionable to or unrepresentative of their broad readership.

Books listed in the 2014 catalogs were categorized by genre to document the types and frequencies of publications. Notes were taken on cover designs, illustrations, descriptions, layout, and presentation on and in the books and catalogs, analyzing how publishers visually frame the written content. Other publishers' titles carried in the catalogs (approved by a review committee) were noted but not analyzed in depth. A selection of frequently mentioned books was reviewed for written content, literary techniques, and visual presentation. Topics and quotes were classified into themes, which emerged, grew, and subdivided. Books were limited to currently marketed storybooks intended for children and/or adults. ${ }^{5}$

\section{Conservative Mennonite Evangelical Separatism in Literature}

In general society, children learn about the world—food, ethnic clothing, language, religion, holidays, customs, and geography — through public schooling, storybooks, and electronic media. In formal instruction, children are given a positive, albeit stereotypical, view of other cultures. They may also be exposed to other cultures in large, consolidated schools. As they grow, they develop views of other cultures. In today's liberal age, respect for other cultures is emphasized as good citizenship. Being religious separatists, Conservative Mennonite children have less exposure to diverse others in personal interaction and electronic media. Further, in school, social studies is one of the least coordinated subjects. History and geography are inadequately presented subjects due to the absence of a clear interpretive framework. Thus, storybooks have an oligarchy on introducing and shaping children's views of other cultures. Readers used in Conservative schools (including Mennonite and Protestant textbooks) feature missionary stories to pique children's interest in spreading Christianity. Protestant texts depict famous missionaries as heroes (e.g. Livingstone, Nate Saint, Jim Elliot, and Amy Carmichael).

Today, missions remain a means for young adults to see the world, adults to vacation,

\footnotetext{
${ }^{5}$ Two exceptions were made. Though a preschool book, Red, Yellow, Black and White (TGS) was included because its explicit discussion of mission awareness, impoverished conditions, and giving. Christian Light Publication's Tangle with Fear is not in current catalogues but is valuable in understanding perceptions of Amish.
} 
families to expose the children to a third world country, and everybody to see how the books confirm their views of "natives," "nationals” or "community people.” Children may absorb some information from relatives who travel abroad as a worker or tourist, hearing stories and seeing pictures and souvenirs they collect.

In spite of their evangelical outlook, Mennonites still emphasize a separatist-based two kingdom philosophy. Believers are citizens of God's kingdom; the world and its system are ruled by Satan because of the Fall. Mennonites see the need to go into the world to help people find Christ, to have forgiveness from God, and to be saved from sin, yet to remain separate from the world in the process.

This section first addresses two different models of managing missions as separatist evangelicals, that of Rod \& Staff and that of CLP-TGS. It then describes the way old and new themes mix into the new "mission adventure" genre. Finally, because evangelical separatism intentionally engages the outside, this article addresses how Mennonites believe the world views them and their mission efforts.

\section{Rod \& Staff's Model of Separatist Evangelism: In the World but not of It}

Rod \& Staff presents an "in this world but not of it” model of separatist evangelism. Their literature emphasizes the missionary as one who practices Christ's teachings, making Christianity attractive through lived example. Converts are drawn to the church because they see Mennonites living out a high standard of holiness. The narratives focus not on missionaries' extraordinary, personalized attributes but rather the church's common, shared example; the church has a directive role for members' lives. For instance: "We should always live faithfully and joyfully so others will see that the Christian life is a satisfying life and will be attracted to Christ who longs to save them also,"6 or, in another instance, "You must be Christians. I can tell by your kindness and your honest living."7 The behavior and deeds of the Mennonites will tell people that they are Christians.

Rod \& Staff encourages outreach through church planting: a church sends some members to an area without another plain church to establish a presence. This presence is the means to demonstrating a Christian lifestyle and to invite others to join. Jesus is found among the group (the church) instead of the individual missionary. The method is outlined in great specificity in Practical Aspects of Outreach. ${ }^{8}$ Hence, the missionary is an example of how an outsider could be, should he bring himself under the church's direction. In God's Detour, Father invites a man to church instead of pressing for immediate conversion. He invites the lonely widower to find lots of friends at church and for him to discover that God wants him to love Him and that God

\footnotetext{
${ }^{6}$ Hooks, Margaret Anne. Cindy (Crockett, KY: Rod \& Staff), 312-13.

${ }^{7}$ Ressler, Pauline. God's Detour (Crockett, KY: Rod \& Staff), 60.

${ }^{8}$ Martin, David L. Practical Aspects of Outreach (Crockett, KY: Rod \& Staff, 2006).
} 
will supply his need. ${ }^{9}$

Interactions between locals and Mennonites, as well as both groups’ propensity to do good deeds, were relatively equal ("in this world,” i.e. a shared humanity) despite differences in dress, culture, and belief ("but not of it”). They work together, are happy, and share many similar emotional experiences as Mennonites, even if there are religious, social, and economical differences. In Adventures of Mohan, equality is suggested through a picture portraying two boys sharing a hug and comforting one another. The one child wonders why they are different skin colors. They compare different color skin to how God made different colors of birds and flowers. All are equal and of one blood. ${ }^{10}$ Sookie of the Philippines portrays a Mennonite family walking down the street, waving to local people who wave in return. The Mennonites remain in distinctive North American garb even when in foreign lands. ${ }^{11}$ In Daryl Borrows a Brother, Daryl notes that other people on the train are not dressed like them. Mother responds,

Not many people are willing to obey all of the Bible. Probably many people do not know what God wants them to do because they do not read the Bible and no one tells them. There are some people who do know what the Bible says, but they do not obey it. We want to be sure we are doing God's will even if other people don't. ${ }^{12}$

Mother provides an unemotional, matter-of-fact explanation of why outsiders do not observe ingroup practices. She is not condemning outsiders or saying that they are sinful. She then explains that Mennonites need to maintain their position based not on what outsiders do but what they personally know is right. Earlier in the story, she and the family acknowledged that even though outsiders do not do things like the Mennonites, they are just as capable of charitable acts.

'We can certainly be thankful for friends. Even Mrs. Carson did a good deed [gave a dessert as a farewell gift and appreciation]. Her dessert was delicious,' Mother noted. 'I was surprised that Mike offered to help [he was the first one there and offered his truck],' Father put in. 'He has always been a friendly neighbor, but I didn’t expect him to give us a day of work like he did.' 13

The "in the world but not of it" perspective instructs readers to keep at bay immoral pressures of society but not paint the outside in a uniformly bleak shade. Their view of the outside is tinged with an Old Order mentality: that is their way, this is our way, and we must be faithful to who we are. Of course, converts are welcome to join the Mennonites, but joining does require immersion in the group. In this respect, these Conservative Mennonites on the one hand maintain separatist church communities much like Old Orders-focusing on doing what they

\footnotetext{
${ }^{9}$ Ressler, Detour, 172

${ }^{10}$ Grove, Ella. Adventures of Mohan (Rod \& Staff, 1990), 64-66.

${ }^{11}$ Some books are beginning to depict altered, mission-style garb.

12 Sensenig, Janet Martin. Daryl Borrows a Brother (Crocket, KY: Rod \& Staff, 1989), 94.

13 Sensenig, Daryl, 36.
} 
know is right - while on the other hand intentionally welcoming people into their church if outsiders show interest. Their mission program focuses primarily on establishing congregations in places where none exist, making one of their churches accessible. Indeed, the Nationwide Mennonite Fellowship, the affiliation most closely associated with Rod \& Staff, has churches more dispersed across North America than any other plain Anabaptist affiliation.

\section{Christian Light Publications' and TGS’s Model of Separatist Evangelism: Missions to a Fallen World}

The second model of separatist evangelism, stressed by CLP and TGS, is "missions to a fallen world," which sees outsiders as part of a fallen, impoverished society. Like the "in the world but not of it" model, this model stresses both separatism and an evangelistic invitation to join church, but Mennonites emphasize their superior offering against the outside's offering, conversion apart from the church, and absence of sect-defining distinctives. Hence, whereas Rod \& Staff, like Old Orders, assert their religious-cultural strength in a standalone manner (and whose view of outsiders is therefore withholding assessment if not outright neutrality), Mennonites working with this model make a forthright assessment of the outsiders they pursue. That assessment is negative, lest they have nothing to offer outsiders and no basis for separatism. The narrative is that the outside has failed to attain the idealistic Christian expression that Conservative Mennonites embody. Converts' old lives and cultures must be disposed of because past entanglements are corrupted. Local people are "bound by their traditional practices," 14 practices preventing religious assimilation. In Wind in the Cohunes, the church replaces the converts' cultural norms, such as child training practices, which Mennonites see as locals allowing children to get their way. City life, in particular, is framed as extremely wicked, as evident in this California Home excerpt:

Do you think Los Angeles is like Sodom and Gomorrah in the Bible?' [...] 'It seems like Sodom and Gomorrah couldn't have been much worse. I do admire the brave souls who live in Los Angeles to try to make a difference by preaching the Gospel. But we have to be careful wherever we live in this wicked world, that we don't feel at home.' ${ }^{15}$

Satan-possessed lands are the places where people are in the greatest need of the Gospel. Indeed, most North American urban presence is through mission program churches, where low paid staff rotates over time, as the city is something to endure for a time rather than commit to for one's life. An exhausting enterprise, spiritual battles are required to overcome and win souls.

Four major themes constitute the "missions to a fallen world” perspective. First, Jesus dwells literally in people, making them capable of carrying out inhuman feats to win people. This is here termed the "incarnation perspective." The actual church is seen as incidental and

\footnotetext{
${ }^{14}$ Wagler, Elizabeth. Wind in the Cohunes (Harrisonburg, VA: Christian Light, 2008) 190; 74.

${ }^{15}$ Good, Fonda. California Home (Berlin, OH: TGS International 2013), 83.
} 
supportive, but not central. Second, if outsiders are poor and sordid, it is because of their spiritual condition. Mennonites have material wealth and spiritual knowledge, and are thus compelled to offer both to improve others' lives. Third, cultural contact is an opportunity to express cultural superiority. Fourth, the generic term “Christian” is used to self-describe the Mennonites, with the stated goal of prioritizing this core identity over a denominational name. By this, Mennonites are not advocating ecumenicalism. Rather, they are making themselves the ruler by which other religious groups can measure their Christianity. They consequently "other” outsiders by emphasizing a dualism between "us” (the true Christian) and "them” (everyone else). While Old Orders do the same (Enninger 1988), the Conservative Mennonites are intentionally pursuing outsiders on religious terms.

\section{The incarnation perspective}

First, CLP and TGS emphasize the spiritualized individual as the locus of missionary activity vis-à-vis Jesus dwelling literally in people. Outsiders "see Jesus" in the missionary. Therefore, the missionary, as the hands and feet of Jesus, must be active in transporting Jesus' incarnated image to people. A Conservative Mennonite summer Bible school prayer summarizes this perspective well:

May I become at all times, both now and forever, a protector for those without protection, a guide for those who have lost their way, a ship for those that have oceans to cross, a sanctuary for those in danger, a lamp for those without light, a place of refuge for those that lack shelter, a servant to all in need. Amen. ${ }^{16}$

They are skeptical that God protects or saves people without missionaries' intervention. Consequently, inactivity means the loss of lives and damnation of many souls. As stated in California Home, "The Brennemans were needed in Southern California to help these people find Jesus,” and, “the people need the Lord, and that's why we're here.” The weight of Christian responsibilities is great, because if missionaries slack, tragedy may occur or people will be eternally lost. After a forest fire spreads though the area, Olive had a feeling that God answered her prayer to spare the home of their relations and their neighbors. "Maybe [the non-Christians] didn't know who to turn to when they were in trouble. If they hadn't prayed, they'd better be glad that there were Christians who prayed for them” [emphasis added]. ${ }^{17}$ If Olive had not prayed, God may have destroyed more homes.

With this "incarnation perspective," what a person does is "by Jesus" and not the person or church. On one hand, this emphasis resonates well with Mennonite humility, declining praise to self. Yet, by Jesus doing these acts, the acts hold greater authority, and, ironically, boldly empower possessed individuals. As missionaries possessing Christ’s indwelling, outsiders and

\footnotetext{
${ }^{16}$ From an Amish-Mennonite church Summer Bible School attended by the authors, June 1-5, 2014.

${ }^{17}$ Good, California, 24.
} 
the missionaries are held at a notably different level, even in equalizing moments: "We sure don’t want to start thinking we are perfect and can't take lessons from someone less fortunate." "I really think that man is close to the kingdom of God [soon going to become a Christian]." "I guess it's good we're here then."18

Successful converts affirm Mennonite norms and beliefs, and, ideally, come to embody Christ themselves, though how this is accomplished is not detailed. Converts remind Mennonites that their religion is genuine. Statements like " $[\mathrm{I}]$ have heard your testimonies in church, and my own faith has been strengthened. I rejoice with you" ${ }^{19}$ are fairly common. Musikali, from $A$ Good Different, is a convert hero because he is liked by church people, works at a Mennonite nonprofit, and is an illiterate co-pastor. The church is successful because it has a "native" or "national” as a minister at a "spiritually alive church.” Yet, CLP's and TGS's framing gives room for the convert to live individually with or without a church since Christ possesses and guides the individual. The core script of conversion involves contact with a missionary followed by a Christian incantation that changes behavior in such a way as to no longer cause missionaries suffering. Church life, as depicted in the book, is an accessory to the convert's spiritual life. In the rear of TGS books, a detailed plan of salvation is laid out; the absolute final note is that, "Fellowship with a faithful group of believers will strengthen our walk with God," laying out an accessory role for the church in the Christian transformation and devotion of believers.

By providing evidence of missionaries' results, CLP and TGS stories encourage readers to remain active in helping and financing mission organizations. The appeal invokes the incarnation perspective as well at an organizational level. "[It is] because of Jesus ... that I am able to keep helping the children of Jesus Christ Children's Ministry."20 Jesus is the one who makes the work possible, not necessarily CAM as a sponsoring organization. Yet, this framing indirectly affirms CAM as not just another organization but a collection of in-dwelt individuals that transcends faulty, sin-prone human organizations. Christ makes these things possible, and in this way, CAM is inferred as possessing the authority of Christ.

\section{Spiritual poverty as the cause of material poverty}

The second theme states that spiritual poverty causes material poverty. Mennonites must provide both spiritual and material sustenance to help people. Spiritually, the local people are in a "...neighborhood that seems to be Satan's territory,"21 a neighborhood that must be brought to “the Winning Side,” as one book’s title suggests. Mission stories describe foreign cultures and places as dark - invoking metaphors of spiritual blindness - as well as deprived and sinful enemy territories.

\footnotetext{
${ }^{18}$ Good, California. 172; 45; 121.

${ }^{19}$ Yoder, Harvey. A Good Different (Berlin, OH: TGS, 2011), 198.

${ }^{20}$ Miller, Gloria. Some Kind of Love (Berlin, OH: TGS International, 2013), 96.

${ }^{21}$ Hoover, Katrina. On the Winning Side (Harrisonburg, VA: Christian Light, 2010), back cover.
} 
Materially, outsiders are framed as in a sordid state, that they have not attained a high living standard. Photographs accent ills like disease and poverty, but also show locals receiving medical treatment from Mennonites and emaciated people posing with donated products. These pictures concentrate on the emotionalism of deprived conditions and, by implication, the sinfulness of the world. Some pictures are relatively graphic with partial nudity, trauma, and disease. Photographs educate readers about the world's needs, generating donations.

Conservative Mennonites are inclined to believe that poverty's root cause is sin. Since poverty's cause is spiritual, the solution is living a true faith. ${ }^{22}$ Lengthy descriptions of sin situations and poor conditions are given, suggesting that they need the Gospel's touch to be made clean. CLP and TGS titles often stress the protagonist's miserable situation prior to coming to the mission church or program. Missionaries then bring the Gospel and provide both better lives and salvation. Once outsiders "have Jesus," they are on the road to recovery, receiving stability, clothes, food, and a better life with Jesus. In Red, Yellow, Black, and White, North American Mennonite children are taught that other children in the world are poor, diseased, disadvantaged, and hungry. At the end, the missionary brings them the Gospel and now they have food, clothing, and happiness. ${ }^{23}$

\section{Cultural superiority}

The third theme states that Mennonites exert cultural superiority when they are in contact situations. Misconceptions about the outside world surface because of continual distancing during evangelism. Within literature, some misconceptions come across as superiority and sometimes ignorance about the world. Cultural interpretations betray their separatist insensitivity to differences. For example, after reading “Juan,” “Jose,” and “Alicia,” a teacher exclaims, "these Spanish names are quite strange." 24 Besides funny names, one child exclaims that the people were "such dumb people," whereas mother does not correct but says, "Oh, but they were kind and cheerful people. They were really trying to be helpful." 25 Other descriptions of natives are offensive, such as "sweat beaded their flat brown foreheads," a derogatory term implying stupidity. Cultural practices such as the wedding ring are depicted as having superstitious power instead of simply cultural symbolism. In Circle of Love, the main character reflects, "How foolish to think that little gold band would keep her bound to him for life!" ${ }^{26}$ When cultures or actions are not understood, characters often pass judgment or laugh. When a street demonstrator

\footnotetext{
22 This belief likely originates from the value placed on working: hard work plus morality equals good living. Indeed, Moledina, et al. (2014) have shown that among some Amish, church leaders (i.e. the most respected community members) tend to be better off financially than the average member. The same is likely true among many Conservative Mennonites.

${ }^{23}$ Stoltzfus, Dwayne and Lois. Red, Yellow, Black, and White (Berlin, OH: TGS International, 2011).

${ }^{24}$ Martin, Rebecca. A Horse Called Willing (Harrisonburg, VA: Christian Light, 1998), 108.

${ }^{25}$ Wagler, Elizabeth. Sojourn in Africa (Harrisonburg, VA: Christian Light, 2003), 51.

${ }^{26}$ Stauffer, Romaine. Circle of Love (Harrisonburg, VA: Christian Light, 1988), 265.
} 
or performer paints himself like the Tin Man, the Mennonites claim that they are not like him who makes himself look different so that everyone notices them and knows they are different. While the Ten Tribes African group has different beliefs, the Mennonites laugh and say that they are of a different planet. ${ }^{27}$ These comments show Conservative Mennonite cultural superiority, an alternative to other contact situation outcomes, like ecumenicalism or "our people" separatism. Using terms such as “community people," "native," "nationals," and even "the dry wall man” to refer to locals can be derogatory. Native is especially so because it implies a primitive people from an imperialistic age.

Conservative Mennonites express cultural superiority over "them” in at least three distinctive ways: emphasizing physical or social traits as associated with a race and thereby marking them as "other," expressing doubt and mistrust of outsiders, and giving childish readings of outside issues and people.

First, Mennonites use ethnicity and race to characterize “them.” A white German-descent people, Mennonites see race as exotic. The numerous references to the dark skin of Africans imply a grossly Caucasian American Mennonite readership and an environment where western European homogeneity saturates everyday interactions. Examples include the following from the Kenyan-based A Good Different:

His white teeth lit up his otherwise dark face;

[We all need Jesus,] no matter if rich or poor, black or white.

The two brothers, one black and the other white, were united in Christ [by baptism].

There are far more black people in the church than white people [...] There are Kenyans who also teach and lead the singing [...] The most important thing is that we learn together about God. He is the only one who changes hearts. It's not the white people. Not the Kenyans, not anyone else. He is the one you need. ${ }^{28}$

While stressing equality on the surface, a second layer of meaning hints at an "other" status for Kenyan converts, vis-à-vis regular descriptions of racial traits.

American ideals about equality between racial differences are written about more with African cultures than with Hispanic cultures, where racial differences are less distinct. In Latin America, emphasis is placed on missionaries’ authority to lead the church. For example, “The Nicas [Nicaraguans] were eventually convinced that love works. And we were convinced that God wanted to use the testimony of tough love to save souls"29 (emphasis added). In another

\footnotetext{
${ }^{27}$ Good, California, 79; 83.

${ }^{28}$ Yoder Harvey, A Good Different (Berlin, OH: TGS, 2011), 170; 171; 169; 9.

${ }^{29}$ Yoder, Pablo, and Phillip Cohen. Angels over Waslala (Harrisonburg, VA: Christian Light, 2008[1998]), Preface.
} 
story, Maria was “unforgiving, proud and rebellious especially to us in authority.”30

Second, Mennonites distrust and are suspicious of outsiders. Missions are cautious about nationals taking advantage of their programs, as with "handouts." Yet, cautiousness goes handin-hand with suspiciousness. For one, Mennonites are often suspicious about whether a convert is truly genuine. A Salvadoran convert repents from sin and seeks to find a similar church in the United States. Father responds with praise to God for his repentance, cautiously adding that he hopes the man sincerely wants to do what is right. ${ }^{31}$ Descriptions of converts frequently portray drugs, abuse, dysfunctional homes, or alcoholism. If no generic descriptor fits, (s)he may just be “way out there.” In one congregation, Tim is a mutterer and an ex-military man; Bob Julian, a Christian Jew who escaped from the Israeli military; and Jim, a shaggy welder who tells stories that his ranch is worth a lot of money. ${ }^{32}$ Outsiders are described as freakish, having something wrong, or having a distinguished sin.

Joining the church is the balm through which infirmities heal. Yet before showing signs of joining the church, seekers face suspicion and gossip, as Mennonites try to discover what is really true, who they really are, from whom they are hiding, and what they really want. When Bob Julian leaves the church, the men ruminate.

'He asked me if we ever went fishing on Lake Erie when we lived in Ohio.'

'Why did he want to know that?’ preacher Abram wondered, raising his eyebrows [...]

'That wasn't all he asked me,' Dad continued. 'He wondered if we were able to go to any of the little islands off the shore of Lake Erie. And then he wondered if we could take a fishing boat to any of the Canadian islands without going through customs.'

'Not that he wanted to do that,' added one of the church brothers, and all the men laughed.

'That's just it,' Dad said. 'Bob claimed he wanted to take his dad there for a vacation, and he was just curious.'

The men shook their heads. ${ }^{33}$

Whether Bob was guilty or not, the expense, surmising, and mistrust against the outsider opened more doors of suspicion.

The contrast of stranger versus familiar Mennonite is evident in the following California

\footnotetext{
${ }^{30}$ Yoder, Pablo, and Kristy Wadsworth. Angels in the Night (Berlin, OH: TGS International, 2007), 130.

${ }^{31}$ Good, California, 70-71.

${ }^{32}$ Good. California, 74-76.

${ }^{33}$ Good, California, 125-26.
} 
Home excerpt, where two strangers, one a local visitor and one an out-of-state Mennonite, visit the church.

'Looks like we have some visitors,' Dad commented as they climbed out. They all looked at the beat-up pickup truck sitting at the end of the rows of cars. There was a car with Pennsylvania plates too-maybe some relatives of one of the church members [...] [Olive] had gotten a glimpse of the local visitor when she came in, and she thought he was worthy of another [glimpse]. [...] He had long, untrimmed hair and a shaggy mustache. [...] Olive searched the small crowd for the Pennsylvania folks, and sure enough, she saw a young woman on the women's side and a young man on the men's side who fit together pretty well [...] Lots of honeymooning couples stopped by their church, and Dad and Mom loved to find out who they were and see if they could make a connection. Usually they could-either they knew an uncle, or went to Bible School with a friend or something. ${ }^{34}$

In this passage, the local non-Mennonite visitor by his car and unkempt look is deemed "worthy of another [glimpse].” The description of him is short and negative. In contrast, the Mennonite couple who has the church connections is esteemed higher, cleaner, and sweeter, and the descriptions is positive and warm, as if they were family though strangers at first.

Outsiders do not have the manners, customs, and thought patterns of Mennonites, signifying their outsider status in many minutiae behaviors. The rough "dry wall man" is suspected of altering his mind with drugs and works too slowly. The Mennonite man wonders if he has hired too many down-and-outers, but then cheerfully reasons that it is a way of witnessing. ${ }^{35}$ Millie, on the other hand, is a puzzle to the missionaries and other Mennonite families because she is quiet and reflective. They feel that she needs to be pouring out her feelings about her home and personal life to them. They are suspicious, believing she has not yet learned faith, as with accepting what God brings into her life. ${ }^{36}$

A them-and-us mentality persists through other stories as well. After the murder of her husband, Marie returns to Guatemala on business and for closure. The narrator describes her conflicting thoughts, asking God for "healing love and forgiveness toward those whose people had killed [the children's] father” ${ }^{37}$ (emphasis added). The character views the local people, even those they ministered to, as a whole instead of singling out the murderous band.

Third, Mennonites make simplistic readings of complex issues, including people's helplessness in spiritual matters. Portrayals of local people or cultures can be childish, sometimes

\footnotetext{
${ }^{34}$ Good, California, 74.

${ }^{35}$ Good. California, 111-12.

${ }^{36}$ Huber, Through Tears (Crockett, KY: Rod and Staff, 1995) 372-74.

${ }^{37}$ Hoover, Dorcas, Awaiting the Dawn (Harrisonburg, VA: Christian Light, 1992), 110.
} 
in descriptions, other times in basic sentences (especially in dialogue) that suggests primitivism. Even when locals explain their own culture, the missionary determines whether the local is really knowledgeable. When Father cannot find cornmeal, the employee explains that there is no cornmeal but masa in Mexico. “'I see...I'll take your word for it, because I can tell you know more about these things than I do.' Dad laughed heartily, and the friendly Mexican laughed with him."38

Readings of contemporary global challenges reveals a lack of knowledge about the broader world. One example gives a simple reading of migrant workers. The Brenneman family tells the children that the Mexicans have a harder time visiting the United States than they do visiting Mexico. The children decide that it is not fair. Dad explains that Mexicans sneak in to do jobs and American families are happy that they labor in the hot sun. The Mexicans are happy about the jobs, even if they are low pay. They send money back to their families. "I like Mexicans" says their daughter. "I think it's very kind of them to work in the hot sun and then send the money home.” 39 Other comments are similarly condescending in simplicity, such as "The Mexicans are usually friendly [...] and eager to please," 40 and "Oh, Cipriano [a grown man]. If only he could have behaved and been patient” (emphasis added). ${ }^{41}$

Other passages describe the childishness of the locals through their hopelessly elementary spiritual knowledge and either / or decision they must make, such as, "Poor man! What did he know about prayer? How could he expect God to hear him in his wickedness," and

If only you would have decided right there to give your heart to the Lord when the spirit touched you! It would have made the biggest difference in what you are doing right now! A world of difference! An eternity of difference! But you didn’t. ${ }^{42}$

In another case, Jews did not want their Christian tracts. Since the Jews also believe the Bible, the Mennonites figured that they would want them. Mother pegs them as unfriendly. ${ }^{43}$ Harsher depictions suggest Satanic activity: "The devil convinced Cipriano that we would accept his plans." 44

\section{Religious identity as "just Christian”}

The fourth theme states that in primarily identifying as "just Christian,” Mennonites make themselves the standard by which others' religious authenticity is assessed. "Christian” is

\footnotetext{
${ }^{38}$ Good, California, 142.

${ }^{39}$ Good, California, 138-39.

${ }^{40}$ Good, California, 139.

${ }^{41}$ Yoder and Wadsworth, Night, 207.

${ }^{42}$ Yoder and Wadsworth, Night, 293.

${ }^{43}$ Good, California, 81.

${ }^{44}$ Yoder and Wadsworth, Night, 127-28.
} 
often in reference to Conservative Mennonite churches, evidenced by some churches adopting the titles "Christian churches" or "Christian Brotherhoods" without a denominational moniker. They express separation in terms of "for Jesus" and "not for Jesus." Since they avoid the "Mennonite" title, confusion arises as to whether all outsiders are really non-Christians. For example, newly-converted Cindy replies, “No, I'm not a little Mennonite. But I am a Christian. ${ }^{45}$ " Upon seeing the distinctive dress, an outsider may ask what group they are. When the Mennonites respond that they are (just) Christians, that they believe the Bible, the inquirer is unsatisfied, if not insulted. In California Home, the girl, initially inquisitive, rejects the tract when the Mennonites use vague self-descriptors. ${ }^{46}$ Of this same church, one seeker wrote the following: "I have visited some Mennonites [in California]. But they don't call themselves Mennonites, just bible believing Christians. But they look very much like and behave like Mennonites."47

Conservative Mennonites are fundamentalist in interpreting other religions. Mennonites flag differences and false teachings in reinforcing their own beliefs. In Wind in the Cohunes, Rosita says that her church makes people learn the Bible and then practice it; other churches do not, and they are no different throughout the week. ${ }^{48}$ Mennonites take pride in their churches saying,

The level of discipleship necessary to sustain growth and stability is sadly lacking in most churches. This is the unique niche that CBF [Christian Believers' Fellowship] churches in Kenya are attempting to fill. The call to commitment not only in words, but also in distinctive dress and worship practices. ${ }^{49}$

Out of the Depths names denominations in succession, offering opinions of each: Pentecostals are "too energized," the community church is hypocritical, the Orthodox are blindly ritualistic and after material gain, and the Jehovah's Witnesses have a creepy spirit. ${ }^{50}$ One reference even says that the early Apostolic churches were so-called Christians because they still participated in violence, drunkenness, and loose morals. ${ }^{51}$

Conservative Mennonites, in contrast, observe practices that produce a veritable religion. "Rather than high emotions, they felt God's presence. Instead of the music making you cry it was the Spirit and the Word. They loved it." 52 Terms such as "professing” and "so-called Christian” imply skepticism of other religions. Unfamiliar practices and rituals are denounced; they are

\footnotetext{
${ }^{45}$ Hooks, Cindy, 237.

${ }^{46}$ Good, California, 81.

${ }^{47}$ Personal communication.

${ }^{48}$ Wagler, Cohunes, 181.

${ }^{49}$ Yoder, Different, Preface.

${ }^{50}$ Lofgren, Rachel. Out of the Depths (Berlin, OH: TGS, 2011) 167.

${ }^{51}$ Yoder and Cohen, Waslala, 132.

${ }^{52}$ Yoder and Cohen, Waslala, 73.
} 
frequently referred to as "darkness," as with one village church described as "dark and filled with superstitions" ${ }^{53}$ because of empty ritualism. The use of candles and icons are foreign to Mennonite worship. Very few understand their meaning and intended use; they are empty rituals and idols, and narratives imply Catholic and Orthodox members are ignorant about their meaning. An African nun is described as in "strange" dirty white robes [habit], with a big rosary and a small cross, participating in "heathen practices." 54 Other practices are framed as superstitions. When a whirlwind comes through a school yard, some children are frightened and make the sign of the cross, a Catholic observance for mercy or a prayer. The children talk about other rituals that are local to the community until a convert schoolteacher corrects the children: these are superstitions and the Bible says to refuse like-practices. ${ }^{55}$ The sign of the cross, lumped with other non-Christian rituals, is condemned.

\section{Creating a New Genre: The New, the Old, and the Reinterpreted}

Heretofore the norms, values, and orientations of Mennonite evangelical separatism have been described. As a relatively new literary theme, its employment has demanded a new genre in which to be cast.

In Gallindo and Brown's (1995) study of the new Amish genre “nature essay,” he argues that author David Kline grounded his writing in existing Amish values, reinforcing the status quo while innovating within those parameters. The result was a new genre that reflected some social change within familiar, consistent frameworks. For example, while going about a highly valued activity (e.g. farming), the author pauses to make an observation about nature. His perspective is experiential and religious, vis-à-vis God's creation, thus allowing room for some deviation from Amish norms, such as the frequent use of singular first person pronouns, conservationist attitudes, and naturalist vocabulary.

Similarly, Conservative Mennonites have created a new genre, the mission-adventure genre. While it works within many tropes familiar to plain Anabaptists, the genre innovates to create a new outlook on missions. This section probes the change through dissecting elements of the genre and also showing how another familiar Anabaptist theme-suffering-is interpreted in both familiar and new ways.

\section{The mission-adventure genre}

The "mission-adventure" genre is the result of TGS's and CLP's appropriation of evangelical separatism into stories. Mission-adventure stories frame Anabaptist two-kingdom theology as the separated kingdom invading a dangerous, sin-ridden territory to win souls.

\footnotetext{
${ }^{53}$ Wagler, Cohunes, cover.

${ }^{54}$ Wagler, Sojourn, 174.

55 Schander, Leona. Coyotes, Tortillas and Amigos: Adventures of an American Family in Mexico. (Harrisonburg, VA: Christian Light, 2012) 31-34.
} 
Without Christ, this territory is dark and evil: murderers, robbers, mobs, rapists, and extortionists live in a land that is poor, full of disease, and corrupt. While usually set in an underdeveloped country, even in the right places in North America, protagonists face runaway trucks, wildfires, aggressive bears, and wicked cities. ${ }^{56}$

Mennonites' interest in adventure stories is not out of the blue. For one, their adoration of Creation and nature is part of their peoplehood. Additionally, they consume a proportionately high level of Wild West, homesteading, and adventure novels (Miller and Aguilar 1984; St. Clair 2005), genres having some overlap with plain people's idealization of hard work, rugged rurality, and so forth. However, these secular fiction books also contain themes, characters, and contexts that are at odds with Mennonite moralizing, e.g. violence, romance, wealth and materialism, dances, etc. Hence, those consuming such books do so quietly and on the periphery.

Conservative Mennonite publishers, alert to Mennonites’ intrigue with otherwise stigmatized adventure tropes, have appropriated these books’ profane themes for sacred ends. Action is depicted as aggressive, hand-to-hand combat with the devil or other evil, to the end of God saving men through mission work. Keywords such as power, winning, score, and wrestling ${ }^{57}$ suggests a warlike attitude toward evangelism. States one book, "you can imagine how the devil felt when [...]." ${ }^{58}$ Like secular adventure stories, mission-adventure stories feature suspenseful and extraordinary victories. Miracles happen often, evidence of God's work: angel sightings, language translations, and narrow escapes. Such witness to God's power, God's presence, and God's veritable involvement, Christianizing the genre. Descriptions of the metaphysical world are most explicit in Pablo Yoder's missionary stories. In Angels in the Night, angels scared off suspected robbers. Yoder begins this account stating, "Let's imagine the scene. The young robber is nervous [...]." ${ }^{59}$ Here, the preface of "let's imagine” skirts the empirical demands of skeptics while allowing room for the events to have unfolded exactly as written. Those who want to believe can without insisting that the details are verifiable.

Mission-adventure stories reward suspense with religious affirmation. Victories are gushingly celebrated in the church context vis-à-vis intense, spontaneous, and genuine religious expression, as illustrated in A Good Different: "[As he was preaching,] Freeman spoke simply but with feeling" and his voice "rose in excitement;" "a chorus of amens followed the statement;” Joyce sees someone standing and crying; tears were "healing tears;” Joyce gives an oration praising Jesus and His transforming power in front of the congregation. ${ }^{60}$

In appropriating adventure genres, Conservative Mennonite publishers satisfy two sacred

\footnotetext{
${ }^{56}$ Good, California Home.

${ }^{57}$ Hoover, Winning.

${ }^{58}$ Yoder and Cohen, Waslala, 192.

${ }^{59}$ Yoder and Wadsworth, Night, 214.

${ }^{60}$ Yoder, Different, 171-74; 187.
} 
ends. First, mission-adventure books inoculate readers against defection by illustrating society's wickedness all the while entertaining the reader with those same elements. Literature provocatively evokes highly descriptive, emotional accounts of the world in its worst state. Dorcas Hoover, in Awaiting the Dawn's first seven chapters, describes a one-night robbery and murder of a Guatemalan missionary. The long, dramatic unfolding engrosses the reader through descriptive language; for example, “the evil sneer on the murderer's lips and cold, merciless eyes of steel."61

Second, mission-adventure books evidence evangelical zeal to a North American readership that embraces evangelistic theology but witnesses little of its products. Mennonite revivalism emphasizes that Christian life is evidenced through excitement, vibrancy, and being “on-fire.” These missionary stories are the epitome of what many Mennonites feel the Christian life should be like. Yet, North American Mennonite church services and outreach programs remain orderly, predictable, and ritualistic, bearing more resemblance to Old Order services even if several programmatic forms are borrowed (e.g. Sunday school and protracted meetings). Hence, they retain stable forms that lend to separatism and inter-generational continuity even as theology has adjusted. The intensity with which foreign missionaries ally with God's legions, strive with evil, claim souls, and celebrate victories demonstrates to North American Mennonites the veracity of their evangelical emphases, allowing them to cognitively lick the fruits of their beliefs even while their domestic system bears more quotidian resemblance to Old Orders.

In advancing these two religious objectives - inoculate plain people to defection and evidencing evangelical zeal-publishers nevertheless retain two core elements of what makes secular adventure novels entertaining: action and superheroes.

First, the mission-adventure genre's effectiveness is that readers are rewarded with a thriller novel as they internalize the two sacred goals. The church's invasion of the dark world is the foundation for an adventure plotline. The thrill of foreign lands, treasure, and adventure provides an exciting context for winning souls in a lawless frontier. Missionaries face violence, attempted rape, power plays, crime, tragedy, degradation, narrow escapes, temptresses, and other suspenseful action. For example, on the cover of Justin's Jungle Adventure, ${ }^{62}$ Justin is donned in Indiana Jones explorer attire as he dashes through the jungle. By implication of publisher insignia, his quest is not for an ancient artifact but for a religious plunder. Nevertheless, the means to both ends fall not far asunder, providing entertainment on the way to a sanctioned goal.

Second, legendary heroes have arisen among the Mennonites: Urie Sharp, Pablo Yoder, Eli Glick, and others are conversational buzz names. These superheroes are looked to as legendary in their idealistic devotion to religious pursuits. They allow readers to feel good about themselves because of their oneness of mind with the hero who is otherwise just a common man.

\footnotetext{
${ }^{61}$ Hoover, Awaiting, 99.

${ }^{62}$ Currier, Mary. Justin’s Jungle Adventure (Harrisonburg, VA: Christian Light, 2011).
} 
Protagonists are like noble superheroes, who, without their costume, are just common men exemplifying widely-held human ideals. For example:

He looked like a regular man — a very thin regular man—but Olive found it fascinating to see someone she read about. A lot of what he said was in the book, but it was different to hear it from the lips of the man who experienced it [...]. It seemed a that a man as old and wise as Eli would understand everything about God. ${ }^{63}$

In the past, autobiographies were unusual since Mennonite publishers encouraged biographies to be published posthumously, but this position is bending. Once a book is written, the individual achieves superhero status. He is asked to speak in North American churches and his fame draws gawkers to the mission. ${ }^{64}$ Some missionaries shun the publicity and adoration; yet young people look up to them in awe like sports or movie idols. Younger generations see missionaries as role models:

Olive loved missionary stories. She hoped to be a missionary herself someday and she really loved reading stories of thrilling missionary escapes. She admired the people who were brave enough to live under dangerous circumstances. ${ }^{65}$

These heroes represent models of "real missionaries” by sacrificially giving "their all” for Christ.

In summary, the mission-adventure genre embodies evangelical separatism in two ways. First, it teaches about the evil world in descriptive terms, deterring defection. Second, it affirms evangelical theology to a North American population who otherwise experiences unrest synthesizing Old Order elements that makes separatism possible with evangelical theology's expressiveness, spontaneity, and outward focus. Mission-adventure books hold readers' attention in two ways also deployed by popular adventure stories. First, they construe the outside as a terrain on which thrilling battles occur to the end of saving souls. God is allied with the missionaries and intervenes in metaphysical ways. Victory is celebrated through gushingly honest expressions. Second, books create overly likeable protagonists that take on superhero proportions. Unlike secular adventure stories, the Mennonite reader can feel conscientiously clear consuming such thrillers because the protagonist is a co-religionist and, by this very fact, is assumedly advancing shared sacred goals.

\section{Suffering for Christ}

While on the one hand missions are adventures, the flip side is missions as suffering. The suffering theme is not an essential ingredient to the mission adventure genre, but it is a classic theme in books advancing separatist evangelism. Suffering for Christ is central to the Anabaptist

\footnotetext{
${ }^{63}$ Good, California, 130-31.

${ }^{64}$ Yoder and Wadsworth, Night, 165.

${ }^{65}$ Good, California, 130.
} 
collective memory, as religious persecution through fines, exile, and execution was a centuries long reality in Europe (Loomis and Beegle 1957). The suffering trope has changed face in new contexts. The present Old Order mentality developed upon migration to America when, given persecution's evaporation, expectation of outside opposition had to be altered. Many Anabaptists adopted a new emphasis, willingness to die to self-will, to yield to the community in Gelassenheit (Cronk 1981), and to endure life’s difficulties, like personal losses, illness, and deaths (Enninger 1988). Cronk goes on to argue that those Anabaptists adopting evangelical thought dampered the “die to self” emphasis, triggering generational assimilation by undermining community togetherness.

Yet, a significant minority of evangelical plain Anabaptists did not assimilate. Instead, they yet again converted the sacrifice and surrender theme to their new framework. Sacrifice and self-giving - first realized through the expectation of persecution among European Anabaptists, second realized through the Old Order emphasis on yielding self to the integrated religious community and God's order and timing-became for conservative Anabaptists giving up personal wants or desires when the community or God calls you to mission work. The new emphasis is actually a hybrid of the first and second waves of the suffering theme: the first suffering was related to the outside's rejection of the Anabaptist religion-though now through Anabaptists' active engagement with the outside rather than vice versa-while the second suffering was related to accepting God's and the community's direction and norms-though now to God as revealed personally rather than communally and to the norm of highly structured, denominationally sponsored missions.

What do conservatives sacrifice and suffer? Certainly mission programs require funding, but giving is assumedly within comfortable means, as influential community members are often economically secure. One of the greatest losses discussed is distance from family, the most mentioned reluctance and sacrifice of missionary families. Families visit each other throughout the week, leaving those at greater distances feeling alone or "out of the loop." Even though conservatives have automobiles and use air transportation, traveling, even an hour or two, is considered moving away. When serving in foreign missions, conservatives are less likely to make new friends, instead keeping in touch with family back home and eagerly anticipating their visits.

In California Home, even though a cluster of relations are with her, Olive ponders whether life in Ohio is superior to California because Ohio is where "our own” are. Ohio even has a better climate, where Olive could garden like other Mennonites. The book concludes that Olive is willing to sacrifice family relations because who would show outsiders the way "if Christians weren't willing to live in Frazier Park, California?” In God's Detour (Rod \& Staff), the Steiner family was expecting to soon go to British Columbia to visit family. Instead, the family is surprised when they are asked to go to a poor Bahamian island for mission work. The family is downcast. Father asks them to sing Anywhere with Jesus which "strengthens" them. Though they have the option of saying no, such an answer is possibly rejecting God speaking 
through the church; the family reluctantly yields to going. Here, the family feels that missing a family get-together is serious sacrifice. Mission work is not an adventure in this case. The "work of the Gospel” takes on a somber rather than adventurous tone.

A second area of sacrifice is in rejection and difficulty in working with the outside. "Working with" the people and their behavior — often simply a difference of culture-is tedious, potentially even drudgery, and requires patience. Missionaries struggle to get seekers and converts to understand, to act their way. For all their effort in the "cause of Christ," missionaries commonly grapple with a loss of return to their investment: a lack of response from locals and "fruit” from seekers, financial loss, and physical ailments. Yet, these setbacks are regularly met with a rallying call to overcome: "In spite of the exhaustion, headaches and lost pay, Micah and Morgan fight hard to gain ground for Christ.”,66

While outsiders may be more interested in friendship or learning about the Mennonite lifestyle, Mennonites are seeking outsiders' conversions. Yet, converting outsiders comes at a cost, as with the patience needed for listening to potential converts, overlooking their bad habits, and dealing with their problems. In California Home, Doug was woofing down food; Bob was talking too much. Olive decided that they need to be long-suffering with these people to help them to the Lord. Dad was patiently listening, even though he didn't seem to want to. ${ }^{67}$ When they become Christians, they will be less irritating.

Experiencing suffering at the hands of a difficult local comes out clearly in this excerpt from On the Winning Side:

'So was it worthwhile having Dia over?' [...] 'I suppose it was good for both of us, even if I get lice. But, I don’t think Dia really cares about me or learning to do what's right. She didn't say thank you for anything. It feels like she just wants as much as she can get from everyone.' 'I'm sure you're making a difference in her life.' ${ }^{68}$

In this excerpt, Morgan and Abigail focus on whether they are successful missionaries. Morgan and Abigail are worried about Dia's interpersonal behavior (e.g. "I don't think Dia really cares about me," "She didn’t say thank you”). Such quotes reflect a mission outlook where the missionary is heroically embodying Christ through suffering. Suffering comes through the unchristian behavior of the outsider. Conversion is achieved through bringing Christ into the outsider's presence via the missionary and exerting influence that will conquer foreign behavior. Thus, Morgan and Abigail are assessing this relationship in search of behaviors that evidence transformation, behavior that will no longer create suffering to those embodying Christ.

An eventual reward is part of the suffering perspective, whether the early martyrs' reward

\footnotetext{
${ }^{66}$ Hoover, Winning, cover.

${ }^{67}$ Good, California, 86.

${ }^{68}$ Hoover, Winning. 64-65.
} 
of the honor to die for Christ and inherit eternal life or the Old Order's reward of eternal rest from struggle. Among conservative Anabaptists, the reward is both old and new. The old is the eternal reward gained through martyrdom. Readers are reminded that literal martyrdom, through community hostilities or warfare, is yet a possibility, reminding conservatives of their European history. In Awaiting the Dawn, the murder and its outcome is seen as worth it all because they will be rewarded in heaven. In another book, the protagonist states, "We'd rather give our lives than let this mission die. If you want to take me, I'm ready now.”,69

In other ways, the reward is new and specific to their individualizing evangelical emphasis. Just doing evangelical programs brings a personal feeling of gratification. Individuals and families are often reluctant to engage in church outreach activities but then discover a "blessing for themselves” later, as with going to cottage meetings, a scenario repeated in Rod \& Staff materials. In a TGS book, the protagonist reflects: "The evening was lovely. Our hearts were filled with joy because we had told others about Jesus." 70 The message is, doing the church's evangelical programs will make you feel good about yourself. For those who actually experience returns on their labor, a double dose of gratification is promised, as when one protagonist states, "Helping people to the Lord is what makes life truly satisfying." 71 In another story, the missionaries believed they could only do so much in a week's time, but if they "touched one life, it will be worth it." 72 Elsewhere, the same characters state, "Seeing someone come to the Lord is so rewarding!" 73 By being the central person people look to, the individual missionary is the key player for an outsider coming to accept what the missionary believes is foundational to life.

Suffering is an old, familiar theme in plain Anabaptist literature, one adapting to new circumstances. Though not integral to the adventure missionary genre, the idea nevertheless resurfaces and is reinterpreted in Conservative Mennonite literature. In this case, suffering is expressed in new ways, such as separating from friends and family, working with difficult seekers, engaging in mission activities when one would rather do something else, and giving one's life on the mission field if God so wills. The suffering theme is old but new once more.

\section{How Conservative Mennonites Think Outsiders View Them}

Even though some Conservative Mennonites are aggressively mission-minded, they still interact within a stable, secluded social system consisting of family relations and religious coadherents. What they believe outsiders think of them is, therefore, revealed most boldly in

\footnotetext{
${ }^{69}$ Yoder and Cohen, Waslala, 51.

${ }^{70}$ Good, California, 67.

${ }^{71}$ Yoder and Cohen, Waslala, 67

${ }^{72}$ Good, California, 151.

${ }^{73}$ Good, California, 121.
} 
convert books. Tellingly, converts themselves have written none; ${ }^{74}$ all biographies are built from interviews (which are reframed if needed), interpreted and written by Conservative Mennonites or related plain co-religionists, and screened during editorial review to remain orthodox. This maintains the affirming self-image consumers seek and cultural producers at publishing companies cultivate.

Books do not strive to get into the mind of outsiders and their view of Mennonite beliefs and practices. Rather, literature insinuates, conjectures, and employs isolated quotes consistent with self-images. Conservative Mennonites propagate three interpretations of how outsiders understand them. First, piggybacking off America's popular fascination with the Amish, the Conservative Mennonites believe outsiders see Mennonites as distinctive traditional Christians upholding religious values from America’s past. Second, Conservative Mennonites believe outsiders see Mennonites as true Christians, which differs from "distinctive traditional Christians" in its emphasis on the abstract spiritual world. Finally, they believe outsiders see them as Christian teachers, who, competent in spiritual matters, are the sages and channels of Christian wisdom.

\section{Conservative Mennonites as distinctive traditional Christians}

Popular depictions of the Amish (Harasta 2014; Weaver-Zercher 2001) have influenced Conservative Mennonites' understanding of how outsiders see Mennonites. Since the plain Anabaptists are often framed as frozen in time, as traditionalists - with the Mennonites being slightly less so than the Amish - they, like the surrounding tourism industry, accent select organizational and material elements of this construct to appeal to outsiders, often those accents with Christian overtones. Inasmuch as Mennonites are aware of their depiction as traditionalists, they naturally extend this to what is most important to them, being traditionalist Christians, not just Victorian era American relics, as is often framed in popular and tourist images (Trollinger 2012).

A group went to Hollywood Boulevard to evangelize through singing. While the celebrities do all sorts of things to get attention, the story notes, the Mennonites came in their "long dresses and head coverings or plain pants and shirts" and people were taking pictures and shooting videos of them. ${ }^{75}$ The Mennonites, realizing they are a cultural novelty, believed that the attention was ultimately because of cultural forms that emanate a material and behavioral Christian witness. The Mennonites were conscious of their presence's power, interpreting outsiders' curiosity with prevailing self-narratives about what their core offering is (genuine Christianity) and what is tangential and incidental (quaint dress and cultural mannerisms).

\footnotetext{
${ }^{74}$ Several conservative publishers, including Vision Publishers and Amish-Mennonite Publications, have published autobiographies, but the three leading publishers have not.

${ }^{75}$ Good, California, 77.
} 
Simplicity and plainness is one reoccurring theme of traditionalist Christianity emphasized in texts. An Eastern European mission church is described as,

[...] bare walls and neat rows of wooden benches. Up front there was a pulpit, but no icons in sight. [...] The women all wore long, simple dresses and white veils on their heads. The men all dressed simply too. ${ }^{76}$

The narration continues to note that they were reverent and sincere in prayer, orderly and harmonic in music, earnest in speech, and warm and friendly in manner. Such descriptions highlight the simplicity of the dress, worship, and building. The outsiders see these as refreshing and beautiful. Another traditionalist Christian emphasis is family integration and affection. For example, the evangelical revivalist theme of a grandmother's or mother's prayers has been appropriated to remind seekers of their grandmother or mother and the paired warmth of family and religious devotion. In California Home, Mennonites sing revival tunes with these themes in public, hoping to trigger in listeners a memory of their mother or grandmother, thus leading them back to God. ${ }^{77}$

Through this script, the readership is reminded of core ideals Mennonites embrace, such as simplicity and family, and that outsiders see these characteristics in Mennonite practice. The function of such depictions is in coping with North American Mennonites' adjustments to materialism and social changes (Olshan and Hall 1991), where in absolute terms the North American Mennonites’ practice is increasingly altered and destabilized, as with greater acceptance of decorated sanctuaries, stylish elements in garb, digital media and technology (Smith 2013), and modern models of family life (Anderson 2013). Yet, despite such anxieties and conflict over this destabilization, the fact that outsiders still read traditional Christianity into their practices affirms that they have not strayed too far.

If the Conservative Mennonites have so much to offer through their tangible practices, how do they explain why few convert? They believe few are willing to "give up things" in order to become a Mennonite. The Satan-ruled world has a grasp on people; outsiders love the world too much to convert. Conservative Mennonites see themselves as too radical or too different for outsiders. These differences are both a visible tool for witnessing and a filter for half-hearted seekers. As one outsider is quoted, “I certainly wouldn't qualify to be saved [...] but I am not ready to take the radical stand you folks take."78

\section{Conservative Mennonites as (abstractly defined) true Christians}

The next image Mennonites believe outsiders see in them is apart from the organizational and material witness; it is an abstract, undefined true Christian radiance. Mission-minded books

\footnotetext{
${ }^{76}$ Lofgren, Depths, 186-87.

${ }^{77}$ Good, California, 81.

${ }^{78}$ Mast, Dorcas R. The Only Sister (Crocket, KY: Rod \& Staff, 2005), 275.
} 
carry a type of White Man’s Burden, a superior status monopolizing "having Jesus” in fullness. Statements such as, "It was so nice. They were there waiting to receive us as if we were Jesus"79 evidences this outlook. People look to them as the answer to finding Christ, such as, "We want to remember to be a good testimony to the community. We are the only Bible some of them read." 80

Many Conservative Mennonites also believe that, because they are Christians, they should be joyful and cheerful, having a "mountaintop experience" against the experiences of the outside world. Rod \& Staff consistently emphasizes having a cheerful attitude and a positive outlook at all times, suppressing and conquering negative, selfish thoughts. CLP and TGS teach that hardships are overcome through learning to be positive or by rallying like a warrior to the cause of Christ. Stories suggest outsiders see Mennonites as happy, friendly, and peaceful people; for example, "she says [the white men] are friendly," "remembering the white man's pleasant smile,” and “They're so happy and peaceful." ${ }^{81}$ Outsiders see Mennonites’ utopist happiness as arising from Christ's light. These stories set high ideals for readers that must be continually sought through inner, psychological means. A wrong attitude or harsh words could turn a person away from Christ, who could consequently be eternally lost.

Of course, while Conservative Mennonites are indeed conspicuous, people foremost observe their dress, clannishness, and cultural mannerisms, not some abstract, supreme Christian persona. Indeed, outsiders have a vague idea of what Conservative Mennonites represent religiously, evidenced by keen notice of apparent deviation, but it is far from the Christian ideal. Thus, the Mennonite construction of how outsiders see them is partial toward reiterating that Mennonites are doing what is right, reaffirming their existing programs built on their responsibility to outsiders.

When converts come to church, they are depicted as finally finding a religious and social home, reiterating the veracity of the Mennonites-as-true-Christians perspective. One character's...

...heart [was] filled with an incredible joy. And she surveyed the group of faces now called her family. She knew she would never want to belong anywhere else. She loved them, and they loved her in return. God in His faithfulness had led her here, and she would do all she could to build up this community of believers. ${ }^{82}$

Because God led this person to the mission church, Mennonites feel that God's divine hand directs seekers to the truth found in their churches. Readers in turn see themselves as idealistic examples and the foremost church.

\footnotetext{
${ }^{79}$ Yoder and Wadswoth, Night, 212.

${ }^{80}$ Good, California, 95.

${ }^{81}$ Yoder, Different, 179; Huber, Tears, 2; Ressler, Detour, 168.

${ }^{82}$ Lofgren, Rachel. Out of the Depths (Berlin, OH: TGS, 2011), 214.
} 
Reading about how outsiders, during the process of seeking the church, view Mennonites provides readers with satisfaction that "Jesus is truly among [us]." Books recount that seekers found a place to belong, that a hole was filled in an empty life. Coming to the church provided Jesus to satisfy spiritual longings and the church people to satisfy friendship longings. "Just the [Mennonite couple's] presence had filled a place inside of Millie that had always been empty before [...]. She still felt that they were her people-her own kind," 83 and, "It was a longing to find the place where her heart belonged, to 'plug in' and be a part of the body of Christ." ${ }^{84}$ The Mennonites bring “security and hope” to seekers' struggles and disappointments because they bring Jesus as the answer. ${ }^{85}$

The "true Christians” and "traditional Christians” perspectives can be complementary in some cases, mutually exclusive in others especially outside North America. A Kenyan says, "They do have some strange ways. There are many things they still do not understand about us Kenyans, but one thing they do have is love. They have love because they have Jesus." ${ }^{86}$ The Kenyan states that the Mennonites' strong Christian testimony conquers perceptions about them as a culturally "white man's church," which has caused "some suspicion and had brought special challenges to the work. [...] The rumors are [...] dispelled by the testimony and changed lives of the Kenyan believers." ${ }^{87}$ Whether true or not, Mennonites believe that the Mennonites-as-atraditionalist-religion image is less noticeable in third world contexts.

With accounts of seekers finding satisfaction and utopia, readers discover that Jesus is the answer to the outsiders' struggles, and the means of finding Him is through the efforts of Mennonites and their mission programs. Thus, the readers are reminded that they are an answer because they are true Christians, though unlike the traditional Christian perspective, what makes them true Christians is not defined in tangible terms, even avoiding doctrinal terms. Convert stories stress this compare and contrast, between the seeker without local Mennonites and the seekers who have contact with Mennonites.

\section{Conservative Mennonites as Christian teachers}

Conservative Mennonite literature portrays a society that sees Mennonites as teachers of the Word and gladly welcomes their offerings; for example, "I was invited to a church called Christian Believers Fellowship, and there I heard so many wonderful teachings about Jesus,” 88 and,

Finding a place where they learned about Jesus and especially the fellowship of the

\footnotetext{
${ }^{83}$ Huber, Tears, 28.

${ }^{84}$ Lofgren, Depths, 205.

${ }^{85}$ Wagler, Cohunes, cover.

${ }^{86}$ Yoder, Different, 169.

${ }^{87}$ Yoder, Different, intro.

${ }^{88}$ Yoder, Different, 168.
} 
church met their need: 'It does a lot of good [...]. I am learning so much about Jesus there, and I love to worship with the other Christians [...] people who love God. ${ }^{, 89}$

The teaching role experiences the most conflict in foreign contexts, suggesting animosity between Mennonites as teachers and the local culture that does not want to learn, but nonetheless recognizes their role as teachers. This conflict subsides when locals change and come to learn. Conflict arises again when the convert rejects the Conservative Mennonite as teacher, as when the convert is required to reject his former culture for the church's, the convert challenges Mennonite authorities (or is perceived to), or the church interferes in the convert's family affairs, especially when the family has not all converted. Many such cases result in excommunication. Readers are reminded that the Mennonite teacher is authoritative because he has access to truth; rejecting the teacher is rejecting the truth, and locals should know better.

North American-based stories depict greater equality, though Mennonites are still the bringers of the truth, presenting the right way of living Christianity. North American stories depict Mennonites giving tracts, singing for others, teaching Bible school, preaching, giving dessert plates to neighbors, and sending children to help others, all the while emphasizing being a light to the world. For example, when concrete workers brought some "bad habits" to his home, father gives them "papers to read" (tracts), wherewith the workers politely respond with an eager thank you. ${ }^{90}$ Along with teaching, Mennonites view themselves as helping, helping people turn from immorality like smoking in this case. Mennonites occasionally witness to neighbors, sometimes inviting them to church, other times just witnessing to them. In stories, when Mennonite families are depicted conducting cottage meetings, ${ }^{91}$ order and rigidity pervades. Father reads Scripture "very distinctly" so that the unlearned Christian is able to grasp its meaning. ${ }^{92}$ Homeowners are thrilled by the visit and by their enthusiasm and happiness.

\section{Discussion}

Like other media, Mennonite literature socializes, sets norms, and guides readers' thinking. Mennonites are aware of literature's power and cultural influence and therefore closely regulates what comes to print or is allowed in their catalogs. Of the three main publishing companies, there are two categories: the church-based Mennonites, or type-one, that tend to be more traditional (represented mostly by Rod \& Staff) and more progressive mission-minded churches, or type-two (represented by CLP and TGS).

Set in ordinary day-to-day settings of typical church communities, type-one literature

\footnotetext{
${ }^{89}$ Yoder, Different, 178.

90 Sensenig, Daryl, 78.

${ }^{91}$ Cottage meetings are home visitation with Bible instruction and singing, typically for non-Mennonite neighbors. Around four to seven Conservative Mennonite families go at once.

92 Ressler, Detour, 168.
} 
teaches good character and decision-making skills by directing the reader back to the church. While all three publishers had missions, the church-based literature emphasized the central role of church in these efforts; evangelizing brought people to salvation in and through the means of a church. The emphasis is on being a good example and practicing the teachings of Jesus throughout daily routines. Outsiders will see their lives and become interested in God, often learning more through an invitation to church.

The strong church emphasis is evident in educational materials as well. Type-one literature catalogs of educational material emphasize classroom teaching, opposed to self-paced curriculum, to emphasize obedience, instruction-following, cooperation, and in-depth instruction, all implicitly teaching children how to work together as a church. ${ }^{93}$ Churches represented in this group are more conservative, have a definite dress code for both genders, and stress the family as an agent of the church.

Type-two literature reflects the mission-minded groups, including Christian Light Publications, and especially TGS, which supports CAM's humanitarian aid and works with myriad plain groups under one structure. In style and content, type-two books resemble Protestant inspirational non-fiction and mission adventure books (i.e. Through Gates of Splendor or In the Presence of My Enemies, also popular reading for Mennonites). Settings for these stories are in the exotic dark world and full of suspense. These books emphasize individual conversion as a stand-alone event separate from incorporation into the church. Conversion is independent, immediate, and often individualistic (via a Sinner's Prayer). The born again believer then goes forth in the confidence of the Holy Spirit, as able to function in the world independently (Cronk 1981), using the church as a social, economic, or logistical resource. Christians are a means of seeing Jesus. ${ }^{94}$ Type-two books, especially mission-focused ones, represent the church in a global, non-affiliative context (“Christian church") instead of a locally focused church. The education curriculum of CLP, Christian Light Education, likewise is consistent with their mission emphasis in its appeal to individualized settings like self-pace classrooms and homeschooling, in addition to use in traditional classrooms.

Story construction, plotline (or absence of one), language, and perspective of characters reflect an ethnocentric view of life. The seeming paradox is that, amidst ethnocentrism, their evangelical emphasis forces them to make interpretations of diversity. Therein are major cultural themes reinforced through literature made plain. Four overall themes emerge from the literature that shows how missionaries maintain their cultural system while trying to woo outsiders.

First, mission groups maintain separateness through Americanization, in observing American holidays, maintaining a Western standard of living, complaining about relatively trivial

\footnotetext{
${ }^{93}$ Rod \& Staff 2014 Catalog, 75

${ }^{94}$ The theme is borrowed from mainstream evangelical Christian books and music; for example, the Twila Paris song “Could You Believe” is sung in just, just an a cappella rendition.
} 
inconveniences, having shopping sprees, dining in cafes and western restaurants, hanging out with friends visiting from North America, and enjoying beach life. Lack of knowledge about the people they are living among and errors in cultural interpretation are repeated and accompanied with a lack of a local voice. American wealth and prosperity is highlighted through juxtaposing regular mention of local populations’ poverty against reflections that God has blessed the Mennonites through western wealth. "Separation from the world" takes on a new character in mission work when the globe becomes the world and separation becomes American culture.

Second, Mennonites go out and conduct missionary work like a job, then retreat to their families and intimate networks, where norms, values, and frames are reinforced. While these intimate groups function to root individual members in community orientations, and thereby separatist ideals, they are also a core cause of inequality between the missionaries and converts. Socially integrated groups, which look inward for affirmation, develop superior attitudes toward outsiders because of unfamiliarity with external cultures and the inability to explore due to strong in-group social pressure, as with statements like, “This church and many others [...] drew members by promising an easy road to heaven." 95 Similar accusations of mockery and selfdefense reoccur, yet are ill-informed. Local cultural practices are called strange and different, depicted as quaint or a novelty (implying the person is simplistic and backwards), or deemed forthrightly wrong. Derogatory words for other races and ethnicities are used without knowledge of offense.

Third, Mennonites distance themselves from the world's sins, reinforcing the church's cultural-religious legitimacy and the need of missions. Type-two books in particular mention how they are not like the outside, which is benighted spiritually. Outside cultures are depicted as sin-ridden, framing society through violence, rape, murder, illicit romance, dysfunctional homes, abuse, and alcoholism (i.e. in Joey's Story, Sandi's Anchor of Hope, Out of the Depths, La Catracha, and Lucy Winchester). Insiders anticipate that converts have dysfunctional homes, substance abuse, or family abuse because that is what they read. Of course, while these themes depict a wicked outside, they double as entertainment. Such subjects, informally forbidden in secular reading, are acceptable when God worked in someone's life. Even hints of the sensual are given to illustrate the temptations apart from the church. Under strict censorship, "softly curved lips” slips through to illustrate a temptress to a young Mennonite man. ${ }^{96}$ They are popular by shock value, adding excitement to hum-drum life-or hum-drum North American separatist Christianity_while intercepting readers' actual desire for living outside the Mennonite setting.

Finally, Mennonites prioritize missions’ organizational operation over tangible results. For how much effort and energy that goes into missions, people are fascinated by convert testimonies, and are surprised that an outsider would actually want to be like them. Rather,

\footnotetext{
${ }^{95}$ Yoder and Wadsworth, Night, 132.

${ }^{96}$ Stauffer, Circle, 113.
} 
missions are an investment doomed to an unprofitable return in terms of community transformation. Consequently, efforts circle back to feed the existing church. Mission literature presents missions as self-focused, frequently discussing what they did, how they were a witness or good example to someone else, and what they got out of it. For example, newsletters typically include updates about missionary and former missionary births, marriages, visitors, touring, and other Mennonite-focused news; reflective articles focus on what the missionary is learning about in his personal faith. Mission literature says little about the lives of locals.

This seemingly inverse emphasis is consistent with a separatist worldview: they highlight examples of model Christian behavior so readers can likewise pattern their lives and contribute to community solidarity and functionality back home. For example, in leadership, missionaries see themselves indispensible at solving spiritual problems because they have Jesus and lifelong experience in separation from the world. Indeed, missionaries feel that the locals want them to be in leadership, so missionaries remain the central authorities. Thus, mission work convinces missionaries of their beliefs - that the inside is right and easier to work with than the obdurate, immoral outsiders - nurturing dependence on and appreciation for the Mennonite setting that may have been less apparent in their home communities.

In summary, this article has demonstrated how Conservative Mennonites have coded emerging norms, values, emphases, and orientations in their literature, literature that echoes a plain Anabaptist model of separatist evangelism. The literature demonstrates both a need to reach out to the surrounding world while maintain a separatist ideal of Christian living. Yet, this synthesis is realized differently. Rod \& Staff literature directs members to sacrificing by moving to mission churches that make their type of church available to a new community. CLP and TGS view the outside society and the church in conflicting terms, painting the outside in stark, unlearned terms while legitimizing the Mennonite system by generalizing it to an abstract, true Christianity. The conflict between outside and Mennonite has been built into a new genre, the missionary adventure genre, which both entertains readers with and inoculates them to outside deviance to separatist ideals and moral living. As changes continue to come to Conservative Mennonites, their reinterpretations of the community's relationship with the wider world will be reflected in literature, offering potential follow-up studies in the future.

\section{Endnote}

${ }^{1}$ Jennifer Anderson works as a substitute teacher at the Holmes County Training Center for special needs children. She earned a B.S. in Unified Elementary and Special Education with an extension in secondary English from Keuka College, KY. She can be reached at jenanigan@beachyam.org ; 330-674-1715. 


\section{References}

Anderson, Cory. 2013. "An Evangelical Reorientation: The Contribution of Beachy AmishMennonite Mothers.” Pp. 236-55 in Mothering Mennonite, edited by Rachel Epp Buller and Kerry Fast. Bradford, ON: Demeter Press.

Cronk, Sandra. 1981. "Gelassenheit: The Rites of the Redemptive Process in Old Order Amish and Old Order Mennonite Communities.” Mennonite Quarterly Review 55(1):5-44.

Enninger, Werner. 1986. "The Theme of Ethnicity in the Literature of the Old Order Amish.” Pp. 115-36 in Studies on the Languages and the Verbal Behavior of the Pennsylvania Germans I, edited by Werner Enninger. Stuttgart, Germany: Franz Steiner Verlag Wiesbaden GMBH.

Enninger, Werner. 1988. “The Social Construction of Past, Present, and Future in the Written and Oral Texts of the Old Order Amish: An Ethno-Semiotic Approach to Social Belief.” Pp. 195-256 in Literary Anthropology, edited by Fernandos Poyatos. Amsterdam, The Netherlands: Benjamins.

Fishman, Andrea. 1987. "Literary and Cultural Context: A Lesson from the Amish.” Languange Arts 64(December):842-54.

Fishman, Andrea. 1988. Amish Literacy: What and How It Means. Pourtsmouth, NH: Heinemann.

Galindo, René. 1994. “Amish Newsletters in The Budget: A Genre Study of Written Communication.” Language in Society 23(1):77-105.

Galindo, René, and Constance Brown. 1995. "Person, Place, and Narrative in an Amish Farmer's Appropriation of Nature Writing.” Written Communication 12(2):147-85.

Harasta, Joseph. 2014. "The Amish-A People of Preservation and Profitability: A Look at the Amish Industry in Lancaster County, Pennsylvania.” Journal of Amish and Plain Anabaptist Studies 2(1):23-41.

Loomis, Charles, and J. Allan Beegle. 1957. "Social Processes within Sects and Churches or Denominations.” Pp. 229-31 in Rural Sociology: The Strategy of Change. Englewood Cliffs, NJ: Prentice-Hall.

Miller, Jerome, and William Aguilar. 1984. "Public Library Use by Members of the Old Order Amish Faith.” RQ 23(3):322-26.

Moledina, Amyaz, David McConnell, Stephanie Sugars, and Bailey Connor. 2014. “Amish Economic Transformations: New Forms of Income and Wealth Distribution in a 
Traditionally 'Flat' Community.” Journal of Amish and Plain Anabaptist Studies 2(1):122.

Olshan, Marc. 1988. “Family Life: An Old Order Amish Manifesto.” Pp. 143-60 in The Religion and Family Connection: Social Science Perspectives, edited by Darwin Thomas. Provo, UT: Brigham Young University Religious Studies Center.

Olshan, Marc, and William Hall. 1991. "The Old Order Amish, Social Change, and the Deviance Process.” Presented at the Annual Meeting of the American Anthropological Association. Chicago, IL.

Oyabu, Chiho, M. Ido, and Toshiharu Sugihara. 2001. "Amish Education 1: Analysis of Health Textbooks.” Annual Report of the Faculty of Education, Gifu University, Educational Research 3:129-50.

Scott, Stephen. 1996. An Introduction to Old Order and Conservative Mennonite Groups. Intercourse, PA: Good Books.

Smith, William. 2013. "Continuity and Change in a Southern Beachy Amish-Mennonite Congregation.” Journal of Amish and Plain Anabaptist Studies 1(2):48-68.

St. Clair, Monica. 2005. “Recent Findings on Library Usage Among the Amish.” Rural Libraries 25(1):43-55.

Trollinger, Susan. 2012. Selling the Amish: The Tourism of Nostalgia. Baltimore, MD: Johns Hopkins University Press.

Weaver-Zercher, David L. 2001. The Amish in the American Imagination. Baltimore, MD: Johns Hopkins University Press. 